\title{
LIFE CYCLE ASSESSMENT (LCA) ANALYSIS OF CONCRETE SLAB CONSTRUCTION FOR ESTIMATING THE ENVIRONMENTAL IMPACT
}

\author{
Annisa Nur Rakhmawati ${ }^{1}$, Yatnanta Padma Devia ${ }^{2}$, Indradi Wijatmiko ${ }^{3}$ \\ ${ }^{1}$ Management Construction Department of Civil Engineering, Brawijaya University, \\ Malang East Java, Indonesia \\ ${ }^{2,3}$ Department of Civil Engineering, Brawijaya University, Malang East Java, \\ Indonesia \\ Email address: rakhmanesa25@gmail.com
}

\begin{abstract}
Global warming and air pollution become one of the environmental issues facing the world. the construction sector consumes about $40 \%$ of total global energy. Many strategies have been adopted to improve the efficiency of building construction to reduce material consumption and carbon emissions. One way to find out the environmental impact and carbon emissions produced is with a Life Cycle Assessment (LCA). This study aims to predict the environmental impact of concrete slab construction in two-story dwellings using the Life Cycle Assessment (LCA) approach of the material used with the help of software, namely Simapro 9.0. The scope of the study is the cradle to the grave. The results of the SimaPro 9.0 concrete plate construction analysis, especially in global warming are $1.02, \mathrm{E}^{+07} \mathrm{~kg} \mathrm{CO}_{2}$ eq. The biggest contribution to the manufacture of concrete slabs is the casting process with a value of $1.00, \mathrm{E}^{+07} \mathrm{~kg} \mathrm{CO}_{2}$ eq.
\end{abstract}

Keywords : concrete plates, life cycle assessment, carbon emissions, global warming, SimaPro 9

\section{INTRODUCTION}

Global warming and air pollution become one of the environmental issues facing the world. According to the World Business Council for Sustainable Development (WBCSD) [1] it has been reported that the construction sector consumes about $40 \%$ of total global energy. Another impact of the concrete industry on the environment is related to waste production. Each year the European construction sector produces 850 million tons of waste, representing $31 \%$ of the total landfill $40 \%-67 \%$ of construction waste and demolition of concrete [2].

According to Lopez-Mesa [1] the environmental impact of a building with precast concrete slabs is about $12.2 \%$ lower than cast plates in place. It can be concluded that concrete slabs have a greater influence on environmental pollution.

One way to find out the environmental impact and carbon emissions generated is the Life Cycle Assessment (LCA). The initial stages of LCA are compiling and inventorying inputs and outputs related to the product to be produced. Then proceed to evaluate the potential environmental impacts associated with the input and output of the product [3].

Based on the results of preliminary research in which construction materials are one of the sources of environmental pollution, this study studies environmental predictions from concrete slab construction in one of the two-story dwellings using Life Cycle Assessment (LCA) of materials used with the help of software such as Simapro. 9.0. SimaPro 9.0 is software that is used to analyze the LCA of a product that affects the environment in the process. $\mathrm{GaBi}$ is an LCA software which in this study is used as a validation of the results of the Assessment from SimaPro 9.0. 


\section{LITERATURE REVIEW}

\subsection{Life Cycle Assessment (LCA)}

Life Cycle Assessment (LCA) is a mechanism for analyzing and calculating the total environmental impact of a product in each stage of its life cycle. Starting from the preparation of raw materials, production processes, sales and transportation, and product disposal [4].

\subsection{LCA in The International Standard Organization (ISO)}

There are four main choices to determine the system boundaries used based on the ISO 14044 standard in an LCA study namely [5],

1. Cradle to grave: including materials and energy production chains all processes from the extraction of raw materials through the stages of production, transportation and use to the final product in its life cycle.

2. Cradle to gate: includes all processes from the extraction of raw materials through the production stage (processes in the factory), until before operation.

3. Cradle to cradle: covers the process from the raw material to the end-cycle phase, namely recycling.

4. Gate to gate: includes processes from the production stage only, used to determine the environmental impact of the production steps or processes.

\subsection{Concrete Plates}

Floor plates are thin structures made of reinforced concrete with horizontal directions and loads that work perpendicular to the structural plane so that in this building Plates function as diaphragms or horizontal stiffeners [7].

\subsection{SimaPro}

SimaPro is the world's leading LCA software among industry, research institutions, and consultants in more than 80 countries [7].

The methods used in the environmental impact assessment contained in SimaPro software are ReCiPe, Eco-indicator 99, USEtox, IPCC 2007, EPD, Impact 2002+, CML-IA, Traci 2, BEES, Ecological Footprint EDIP 2003, Ecological scarcity 2006, EPS
2000, Greenhouse Gas Protocol and others [4].

\subsection{GaBi}

$\mathrm{GaBi}$ is a full service-LCA based software program, meaning that the software assists in performing an LCA in addition to providing data. Data is accessed via Thinkstep, an international company focused on sustainability on multiple levels. GaBi software is available in multiple forms, each geared for a slightly different purpose [3].

The $\mathrm{GaBi}$ software system is a leading tool for life cycle engineering, creating life cycle modeling and balances. Life cycle engineering is a method for the assessment of the technical, economic and environmental impacts of products, services, and systems. $\mathrm{GaBi}$ additionally can evaluate socio-economic aspects [8].

\section{METHOD}

The initial step in this research is to determine the goals and scope that aim to provide references and limits on the research. This study aimed to analyze the LCA in concrete slab construction. The scope of the LCA in this study is the cradle to grave where research is carried out from the initial preparation of the material to the process of casting concrete slabs. The second step is inventory analysis. This stage is the stage of input and output analysis of existing data and based on predetermined limitations. The third step in an LCA is an impact assessment or an assessment of the environmental impact of the results of an inventory analysis that has been made. The final step in LCA is interpretation.

The data used in this study are the data volume of each material in the manufacture of concrete slabs, the list of material suppliers under construction, and the transportation used to carry the material.

Data that has been entered into the SimaPro 9.0 software is then analyzed. Data from SimaPro 9.0 analysis can show materials or processes from concrete slabs that have a large contribution to the environment. From the conclusions and alternatives, this data can be applied to reduce the impact on global warming. 


\section{RESULTS AND DISCUSSION}

\subsection{Data Collection}

The location of this research is located in Plaosan Garden Estate owned by PT Adong Property in Malang City. The object of research is 2 story house type 326 with an area

Table 1. Concrete Plate Material Needs

\begin{tabular}{clcc}
\hline No & \multicolumn{1}{c}{ Process } & Material & Volume \\
\hline 1 & $\begin{array}{l}\text { Install } \\
\text { scaffolding }\end{array}$ & $\begin{array}{c}\text { Bamboo } 8 \\
\mathrm{~m}\end{array}$ & $26,9 \mathrm{~m}^{3}$ \\
\hline 2 & $\begin{array}{l}\text { Install the } \\
\text { wooden frame to } \\
\text { support the plate } \\
\text { formwork board }\end{array}$ & $\begin{array}{c}\text { Wood } \\
\text { beam }\end{array}$ & $2,4 \mathrm{~m}^{3}$ \\
\hline 3 & $\begin{array}{l}\text { Install formwork } \\
\text { board }\end{array}$ & $\begin{array}{c}\text { Multiplex } \\
9 \mathrm{~mm}\end{array}$ & 54 sheet \\
\hline 4 & $\begin{array}{l}\text { Reinforced bar } \\
\text { of concrete } \\
\text { plates }\end{array}$ & $\begin{array}{c}\text { Steel SNI } \\
10\end{array}$ & 604 sheet \\
\hline 5 & $\begin{array}{l}\text { steel binding } \\
\text { concrete }\end{array}$ & $\begin{array}{c}\text { Steel wire } \\
\text { rod }\end{array}$ & $29,3 \mathrm{~kg}$ \\
\hline 6 & $\begin{array}{l}\text { Concrete plate } \\
\text { cast process } \\
\text { (ready mix) }\end{array}$ & Ready \\
\hline 7 & $\begin{array}{l}\text { Cast concrete is } \\
\text { vibrated to make } \\
\text { it level }\end{array}$ & Vibrator & $17,3 \mathrm{~m}^{3}$ \\
\hline
\end{tabular}

4.2 Output from Software SimaPro 9.0

SimaPro 9.0 software has various methods in environmental impact assessment. In this study, the method used is ReCiPe 2016 Midpoint (H).

1. Characterization

The ReCiPe 2016 Midpoint method has of $13.5 \mathrm{~m} \mathrm{x} 16 \mathrm{~m}$. The following Table 1 shows the material needs of concrete plates and Table 2 is information on transportation and distance traveled.

Table 2. Information on Transportation and Distance Traveled

\begin{tabular}{clcc}
\hline No & $\begin{array}{l}\text { Name of } \\
\text { Material }\end{array}$ & Name of Store & $\begin{array}{c}\text { The } \\
\text { distance of } \\
\text { supplier to } \\
\text { the project } \\
\text { location }\end{array}$ \\
\hline 1 & Bamboo & $\begin{array}{c}\text { UD Wahyu } \\
\text { Pratama }\end{array}$ & $8,8 \mathrm{~km}$ \\
\hline 2 & $\begin{array}{l}\text { Wood } \\
\text { beam }\end{array}$ & $\begin{array}{c}\text { UD Wahyu } \\
\text { Pratama }\end{array}$ & $8,8 \mathrm{~km}$ \\
\hline 3 & $\begin{array}{l}\text { Multiplex } \\
9 \text { mm }\end{array}$ & $\begin{array}{c}\text { UD Wahyu } \\
\text { Pratama }\end{array}$ & $8,8 \mathrm{~km}$ \\
\hline 4 & $\begin{array}{l}\text { Steel } \phi \\
10\end{array}$ & $\begin{array}{c}\text { Toko Besi } \\
\text { Sinarmas }\end{array}$ & $6,6 \mathrm{~km}$ \\
\hline 5 & $\begin{array}{l}\text { Steel } \\
\text { wire rod }\end{array}$ & $\begin{array}{c}\text { Toko Besi } \\
\text { Sinarmas }\end{array}$ & $6,6 \mathrm{~km}$ \\
\hline 6 & $\begin{array}{l}\text { Ready } \\
\text { Mix }\end{array}$ & $\begin{array}{c}\text { PT. Surya Beton } \\
\text { Indonesia }\end{array}$ & $11 \mathrm{~km}$ \\
\hline
\end{tabular}

various categories of assessment of environmental impacts, namely in terms of global warming, fine particles, fossil depletion, acidification (eutrophication), toxicity, radiation, land use, and the ozone layer.

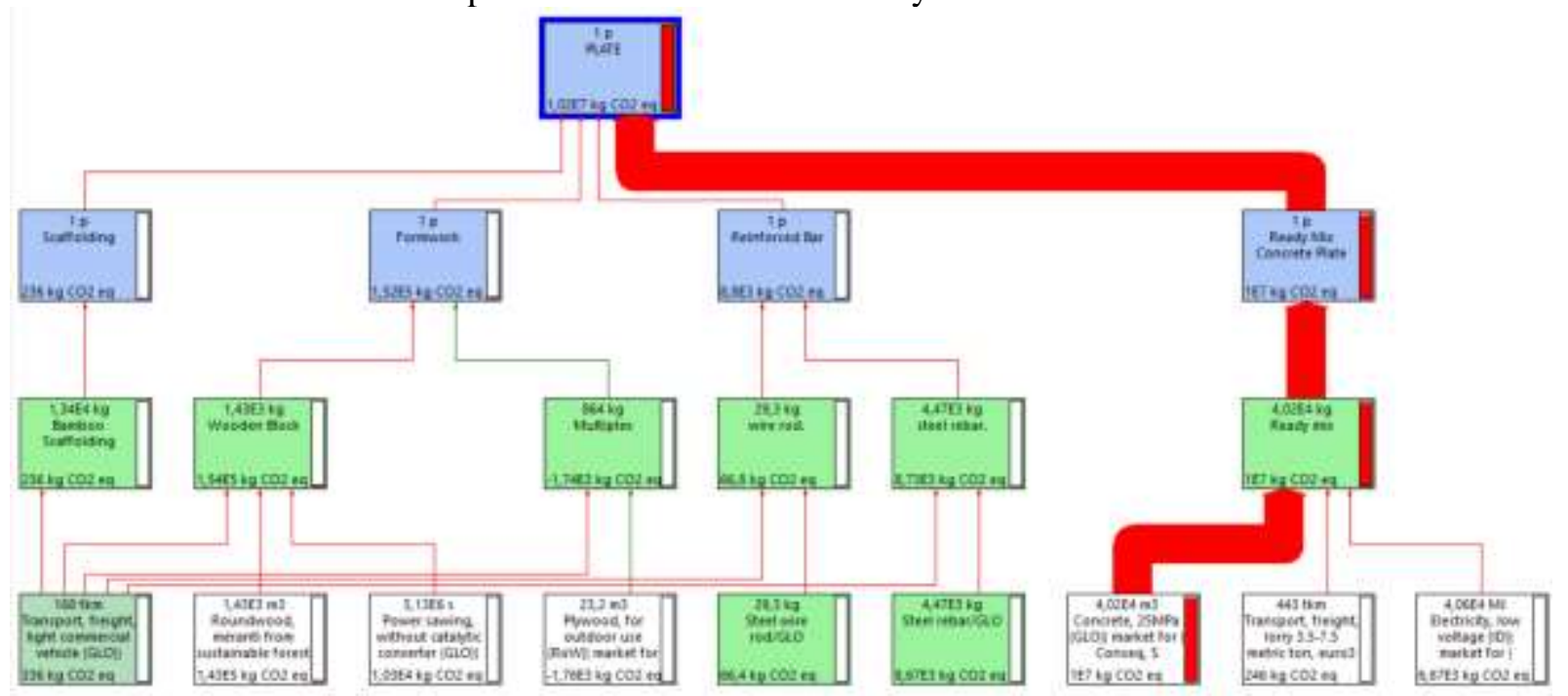

Figure 1. Network Process of Making the 2nd Floor Concrete Plates in $\mathrm{Kg} \mathrm{CO}_{2}$ eq 


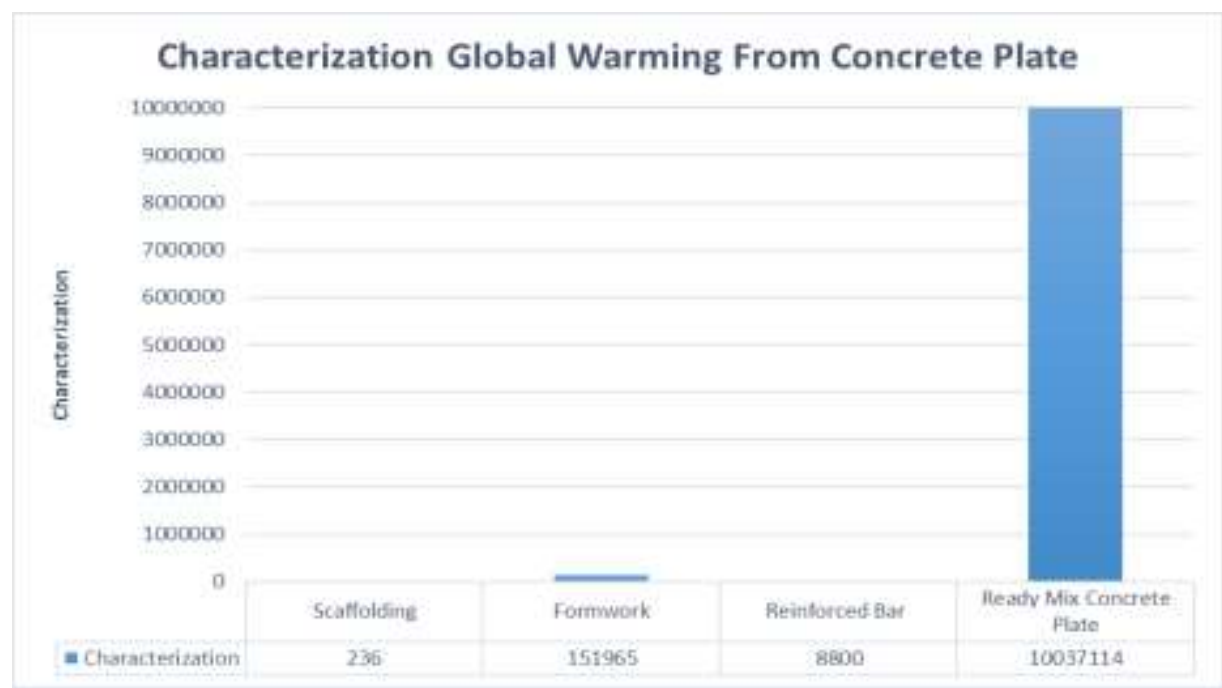

Figure 2. Graph Characterization of Concrete Plates Global Warming

The total analysis results mainly on global warming are $1.02, \mathrm{E}+07 \mathrm{~kg} \mathrm{CO}$ eq, where the biggest contribution is the process of casting concrete slabs with a value of $1.00, \mathrm{E}+07 \mathrm{~kg} \mathrm{CO}_{2} \mathrm{eq}$, then the reinforced bar process of $8800 \mathrm{~kg}$ of $\mathrm{CO}_{2}$ eq, formwork $1.52, \mathrm{E}+05 \mathrm{~kg} \mathrm{CO} 2$ eq, and scaffolding $236 \mathrm{~kg} \mathrm{CO}_{2}$ eq according to Figure 2.
2. Normalization

Normalization is the uniting of units into the same unit, namely units per year for each environmental impact [9]. Normalization results from SimaPro 9 are shown in Figure 3 and Figure 4.

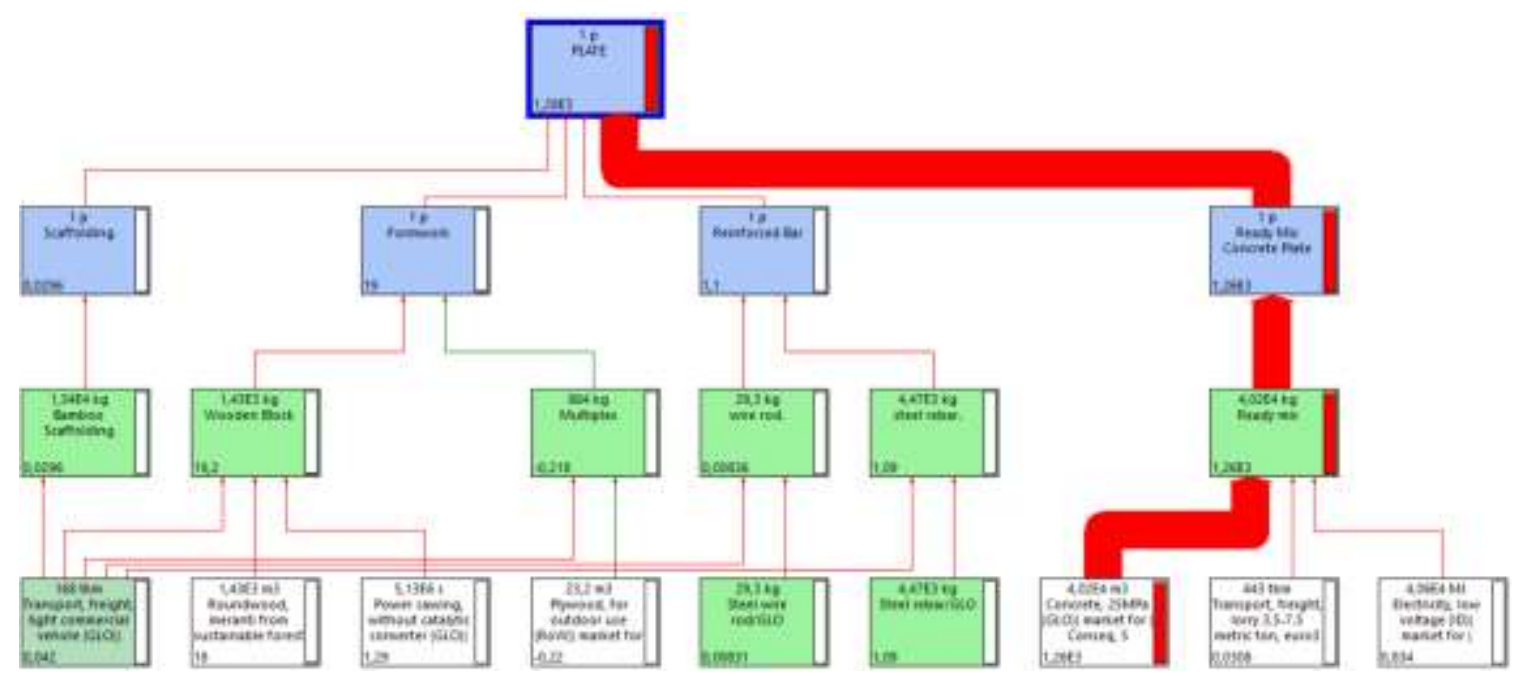

Figure 3. Network Normalization Concrete Plate 


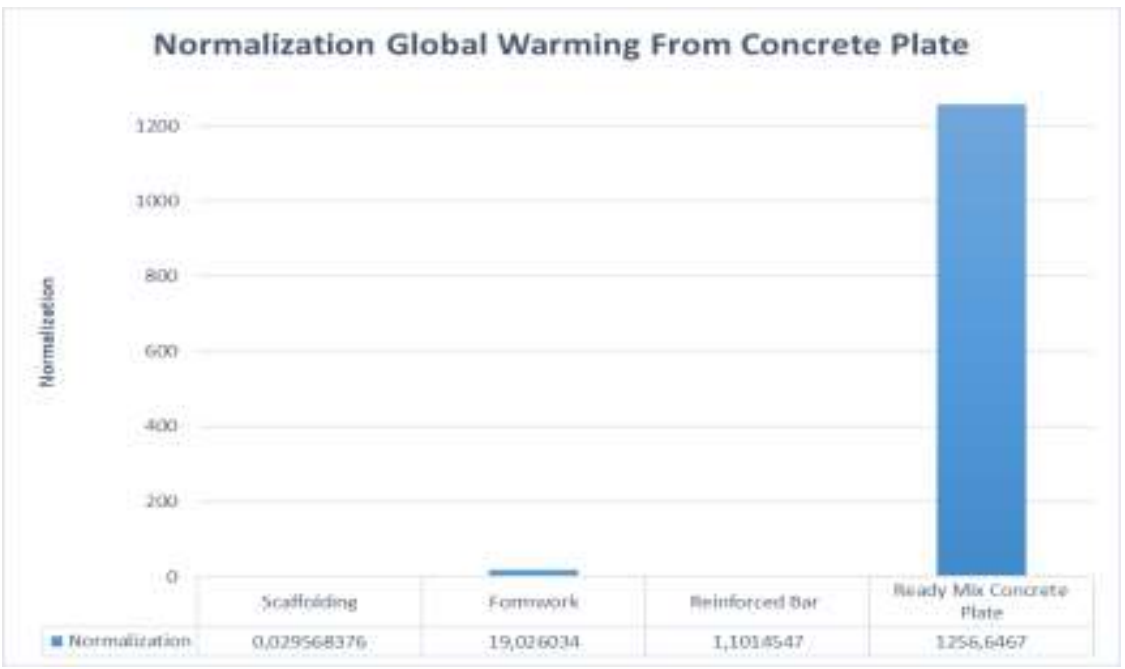

Figure 4. Graph Normalization of Concrete Plates Global Warmin

Table 3. Global Warming Normalization Calculation Results

\begin{tabular}{|c|c|c|c|}
\hline Activity & $\begin{array}{c}\text { Characterization } \\
\text { result } \\
(\mathrm{kg} \mathrm{CO} 2 \mathrm{eq})\end{array}$ & $\begin{array}{c}\text { Gas } \\
\text { Emissions } \\
(\mathrm{kg} \mathrm{CO} \text { eq) } \\
\text { / year }\end{array}$ & Normalization \\
\hline & $\mathbf{E}$ & GG & $\mathbf{N}=\mathbf{E}: \mathbf{G G}$ \\
\hline Scaffolding & 236,16914 & 8000 & 0,02952 \\
\hline Formwork & 151965,1 & 8000 & 19,0 \\
\hline $\begin{array}{l}\text { Reinforced } \\
\text { Bar }\end{array}$ & 8797,6 & 8000 & 1,100 \\
\hline $\begin{array}{l}\text { Ready mix } \\
\text { concrete } \\
\text { plate }\end{array}$ & 10037114,0 & 8000 & 1254,6 \\
\hline
\end{tabular}

Based on the

(1.1)

$$
\mathrm{N}=\frac{\mathrm{E}}{\mathrm{GG}}
$$

$\mathrm{N}=$ Normalization Value

$\mathrm{E}=$ Value of carbon emissions from characterization

$\mathrm{GG}=$ global greenhouse gas emissions per person/unit

The calculation of normalization in this study, especially global warming is shown in Table 3.

\section{CONCLUSIONS AND RECOMMENDATIONS}

\subsection{Conclusions}

Based on the results of concrete LCA research, it can be concluded that the process that has a major contribution to the environmental impact, especially global warming, is the process of casting concrete plates. The process of casting concrete plates has the biggest contribution due to several factors such as the material in ready-mix, namely cement has the biggest carbon emissions in construction. Also, other factors include air pollution generated from trucks when traveling to the project site as well as pump trucks used when implementing concrete slabs.

\subsection{Recommendations}

Suggestions that are expected to be useful for future researchers include the following:

1. Further research needs to be done with a broader scope so that it can apply the waste scenario.

2. It is necessary to deepen the database or inventory in LCA software in the construction sector so that it is expected to provide a detailed analysis.

3. Before determining the object of research, you must first ensure that material or inventory is available in the 
software.

4. The validation process needs to be improved. Not only by comparing other software, but can be done using manual calculations that are expected to produce the same value by the results of the software output.

\section{REFERENCES}

[1] Wang, J., Tingley, D. D., Mayfield, M., \& Wang, Y. (2018). "Life Cycle Impact Comparison of Different Concrete Floor Slabs Considering Uncertainty and Sensitivity Analysis". Cleaner Production, 374-385

[2] De Schepper, M., den Heede, P. V., Driessche, I. V., \& De Belie, N. (2014). "Life Cycle Assessment of Completely Recyclable Concrete". Materials, 6011

[3] Hermawan, Marzuki, P. F., Abduh, M., \& R. Driejana. (2013). "Peran Life Cycle Analysis (LCA) Pada Material Konstruksi Dalam Upaya Menurunkan Dampak Emisi Karbon Dioksida pada Efek Gas Rumah Kaca". Konfrensi Nasional Teknik Sipil 7 (KoNTekS7) (hal. K-47 - K-52). Surakarta: Universitas Sebelas Maret

[4] Pujadi, \& Yola, S.T., M.Eng, M. (2013). "Analisis Sustainability Packaging dengan Metode Life Cycle Assessment (LCA)". Riau:
Universitas Islam Negeri (UIN) Sultan Syarif Kasim

[5] Harjanto, T. R., Fahrurrozi, M., \& Bendiyasa, I. (2012). "Life Cycle Assessment Pabrik Semen PT Holcim Indonesia Tbk. Pabrik Cilacap : Komparasi antara Bahan Bakar Batubara dengan Biomassa". Rekayasa Proses, 51-58

[6] Wisanggeni, D. H. (2017). "Perbandingan Sistem Pelat Konvensional dan Precast Half Slab Ditinjau Dari Segi Waktu dan Biaya Pada Proyek My Tower Apartement Surabaya". Surabaya: Institut Teknologi Sepuluh Nopember

[7] Ponsioen, T. (2014, July 21). "Home: Sustainability news. Diambil kembali dari Normalisation: New Developments in Normalisation". Sets: https://www.pre-sustainability.com/news/the-n ormalisation-step-in-lcia

[8] Anonym. (2012). GaBi Manual. PE INTERNASIONAL AG

[9] Utomo, B. P. (2018). "Identifikasi Dampak Lingkungan Pada Material Pembuatan Batik Cap Menggunakan Metode Life Cycle Assessment (LCA) dengan Software SimaPro 8.30". Surakarta: Universitas Muhammadiyah Surakarta 